\title{
The Influence of Guidance To Solve Problem In English Learning at SMP Al Akbar Brondong Lamongan
}

\author{
Rohmat Qosyim \\ Sekolah Menengah Pertama Al Akbar Brondong \\ Email: rohmat23@gmail.com
}

\begin{abstract}
Teachers sometimes are amazed at the extent to which a child's undesirable habit patterns can be reconditioned through the efforts of understanding teachers. At the same time, home influences may be so strong that there is little that teachers and counselors can do for the child unless he can be removed from unhealthful home surroundings. In most states, the parents have the legal right to device where their child shall live. Hence school people are helpless in such situations unless, by court action, the child is placed in an institution or foster home because of extreme parental neglect of or cruelty to the child, or gross immoral behavior on the part of one or both parents. Based on the background, the writer wants to do classroom action research with the title "The Influence of Guidance to Solve Problem in English Learning at SMP Al Akbar Brondong".
\end{abstract}

Keywords: Influence of Guidance, Solve Problem, English Learning

Many of the adjustment problems of young people seem to reflect unhygienic home conditions. Parental attitudes and home and family situations that may lead to a young person's experiencing problems that need resolution include: family jealousies and dissensions; overindulgent, indifferent, or too strict parents; frequent moving of the family from one section of the city or country to another; too many or too few home duties; differences in ethical standards or religious affiliations among family members; low moral status; lack of home co-operation with the school or the community; homes broken by divorce of the death of a parent; homes that represent a culture that is foreign to that of the school community, and extremely low socio-economic status. (Lester D. Crow, and Alice Crow, 2006:526)

The first six years of a child's life are very important. Hence the six-year-old child who is a product of a home in which there are maladjustive factors is likely to reflect these unfavorable home conditions in undesirable attitudes and behavior patterns. Yet, teachers sometimes are amazed at the extent to which a child's undesirable habit patterns can be reconditioned through the efforts of understanding teachers. At the same time, home influences may be so strong that there is little that teachers and counselors can do for the child unless he can be removed from 
unhealthful home surroundings. In most states, the parents have the legal right to device where their child shall live. Hence school people are helpless in such situations unless, by court action, the child is placed in an institution or foster home because of extreme parental neglect of or cruelty to the child, or gross immoral behavior on the part of one or both parents.

School experiences. A learner may experience difficulties in adjusting satisfactorily to his learning experiences for one or more of several reasons. Some of these interfering factors can be and are overcome with the help of teachers who are alert to disturbing influences. With the aid of the administrative officers and counselors of the school, a teacher may be able to encourage whatever changes are needed to help the learner make a better adjustment to his learning activities. Other learner problems may represent a complex of conditions that cannot be improved by the school without the assistance of parents or other community agencies.

There are certain common situations or conditions that have been found by teachers to retard or to interfere with a young person's satisfactory adjustment to learning requirements. Among these are: lack of interest in school work or in specific school subjects; school curricula that are not graded appropriately to the learner's level of intelligence; too much or too little teacher assistance; poor study habits; too long or too difficult home study assignments; too much or too little competition among learners in terms of ability to compete; fear or failure; learner-teacher antagonisms; inadequate home-study conditions; too much or too little participation in the school's sports program or other cocurricular activities, or out-ofschool social activities; uncertainty about, or parent-child conflict concerning, vocational choice and preparation, and too great or too little parental interest in the child's school activities or learning progress. Some of these problems are experienced especially by secondary-school learners; some of them result from learner attitudes that have their roots in home-stimulated recognition of what should constitute desirable life values.

One of the most important functions of teachers and school counselors is to recondition the attitudes of some young people toward an appreciation of the value to themselves of achieving success in whatever educational opportunities are made available for them. Occupational requirements, social pressures, and educational encouragement are responsible for the fact that the upper limit of compulsory school attendance now ranges between the ages of sixteen and eighteen. There is a trend toward a school-leaving age of eighteen, except in emergency home conditions or in the case of a learner's giving evidence of inability to profit from further formal school learning. In every secondary school, however, can be found boys and girls whose one ambition is to leave school for a job, even though they are not yet prepared to perform adequately in any kind of job. Youth attitudes of this kind place upon 
school people the responsibility either to try to change a young person's attitude toward the value of education, or to offer a vocationally pointed curriculum that will prepare him for a job in which he has some chance of success.

Based on the background, the writer wants to do classroom action research with the title "The Influence of Guidance to Solve Problem in English Learning at SMP Al Akbar Brondong".

Based on the background of research, the problem of this research is as follows: How is the influence of guidance to solve problem in English learning at SMP Al Akbar Brondong?

According to statement of the problem, objective of this study is as follows: To know the influence of guidance to solve problem in English learning at SMP Al Akbar Brondong.

This study aims to develop quality of the students' achievement and to improve in English teaching leaning. The result of the study is to solve the problem in learning to get good achievement and the teacher gives guidance in English learning and teaching.

\section{Review Of Related Literature Guidance}

An understanding of the child is basic to any help or guidance that may be offered in his behalf. If we expect to be of aid to each learner as he attempts to make adjustments to the forces and factors in his environment, then those of us who are given the responsibility of promoting his welfare must prepare ourselves so that intelligent counsel and guidance may be offered. The child is forging ahead and needs to have the way prepared for him. He must come to understand its values and to recognize obstacles as well as him own potentialities as these are operative in his moving along that particular road.

Much has been written on guidance, personnel work, or counseling, yet there is little guidance in the way of its specific application to the actual work of the school. In its largest connotation guidance can be conceived of as being as broad as education itself. Any aid or assistance that is rendered a learner rightly can be considered to be guidance. However, guidance come to be interpreted as a phase of education that functions in relation to child development and adjustment. The functions of guidance are served best when an individual learner so is advised and aided that he is stimulated to make needed adjustments for the realization of his personal and social growth and satisfaction. There is an implied activity on the part of both the person who is being guided and the one who stimulates activities along welldirected lines of endeavor. From the point of view of the authors, "guidance is interpreted as a conscious, organized, directly or indirectly, to assist him in his adjustment to all phases of living. It is the handmaid of mental hygiene in education." (Lester D. Crow, and Alice Crow, 2004:571)

\section{The Influence of Guidance to Solve Problem in English Learning}

Pupils evince the need of guidance in mental activity, in behavior that has individual and 
social implications, and in the selection of a field of vocational work. Seldom can an individual, unaided, make his own choices or his own decisions for his own best interests.

It is true that the need of guidance is more easily recognized in times of crises when life runs along smoothly. However, if the right kind of guidance is experienced as a matter of course, it is wholly possible that a particular crisis confronting a young person can be avoided. It is the duty of the parent, the teacher, or the young leader to discover the personal problems of the young people for whom they are responsible and to help in the resolution of youthful conflicts. Among the conditions or situations that may bother young people can be included the following: physical characteristics, style of clothes, extent and kind of home duties, degree of success in school, recreational activity, degree of security or insecurity, attitude toward others, deciding about a vocation, and any one of a hundred or more real or imagined problems that face the young person during his maturing process.

As we consider the number of maladjusted individuals even in our own immediate environment, we recognize the need for more adequate guidance of child behavior and attitude. Delinquency is born in the environment, but if a child receives the proper help at the proper time he may be saved many trying experiences. "Parental" schools have come, have gone, and may come again. But delinquent behavior continues. As a result of an increase in delinquency, educational leaders in a certain large city are combining at the time of this writing in a recommendation that "bad" boys be segregated in a twenty-four-hour school so that may be trained in a carefully controlled environment. The need of guidance is recognized by any one who works with young people. A person, however, should not be expected or permitted to engage in guidance work unless he has received careful training in the utilization of techniques that have been helpful to workers in the field.

During the early years of the child, the guidance service provided for him center first in the home. When we refer to parental rearing of young children, it might be more accurate to describe parents' activities as those of guiding the child. Later, nursery-school and kindergarten teacher share with the parent the responsibility of introducing the child to the process of adapting himself to the requirements of an enlarging social world. Here the needed guidance activities include those of the teacher, the school nurse, and pediatrician and, of course, the parents. On this level, except in the case of the small child who already has become the victim of maladjustive influences, the main objective of guidance is prevention of difficulties. The youngsters are motivated to achieve self-awareness and self-confidence in their reactions to stimulating objects and situations and in their relations with their peers and older people. 


\section{Methode \\ Design of Study}

The research design in this study was the Classroom Action Research. Therefore the research was aimed at improving the teacherresearchers' own teaching. This classroom action research discussed about the influence of guidance to solve problem in English learning at SMP Al Akbar Brondong.

\section{Subject of the Study}

The subjects of the study were the eighth year students. In this study the researcher selected Class VIII as the subject. The population of students Class VIII was 32 students.

\section{Procedure of Study}

The procedure of research used in this study was a cyclical process adapted from the model proposed by Kemmis and Mc. Taggart. It consists of four steps, namely: planning, implementing, observing, and reflecting. These phases take place in every cycle. If in the first cycle the strategy has not solved the problem yet or the criteria of success have not been achieved, the strategy will be revised to continue to the second cycle. The cycle would continue to the next cycle with the same steps until the criteria of success are achieved.

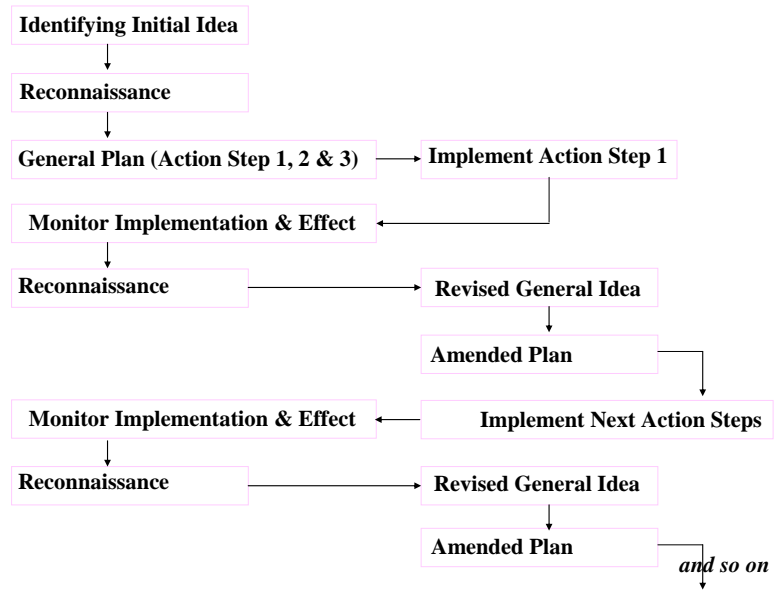

Figure 1: Procedure Classroom Action Research (Elliott)

The first step in planning make lesson plan. Preparing the lesson plan is very important the teaching learning process. It is made as a guide to conduct the instructional activity. The lesson plan is developed based on the syllabus of the school Based Curriculum. Planning should be complete and detail about everything will be done by researcher, include: action with its steps, subject, timing, instrument and so on. The implementation was to conduct the learning activity based on the plan. Observation is the process of recording and collecting data about any aspects or events which are happening during the implementation of the action. Reflection is the most important part of classroom action research. Reflection is a final phase of a cycle in which the researcher and the collaborative teacher evaluated the strength of the action implemented in the class. At this stage, the researcher wants to know the action, which is conducted is effective or not. 


\section{Data Analysis}

Analysis works with data, organize it, synthesize, search patterns, discover what is important and what is learned, and decide what will explain to the others (Bogdan and Biklen, 1982:145). To analyze the statistic data researcher uses mean, because it shows the mean score of students. The formula of mean is as follows:

$\mathrm{M}=\frac{\sum \mathrm{fx}}{\mathrm{N}}$

$\mathrm{M}=$ the mean

$\sum=$ the sum of

$\mathrm{f}=$ frequency

$\mathrm{x}=$ score

$\mathrm{N}=$ number of the subjects

\section{Research Findings And Discussion}

\section{Research Findings}

The First Cycle

\section{Planning}

The first step in classroom action research is planning. It is very important to be done if want to get optimal result action of this research should be planned. To start this study the researcher and collaborator made some preparation before conducting the teaching and learning process including: Determining standard of competence, determining basic competence, making indicators, determining strategy in learning, determining the instructional materials, making the instruments for observation, and preparing media will be used in learning, as follows:
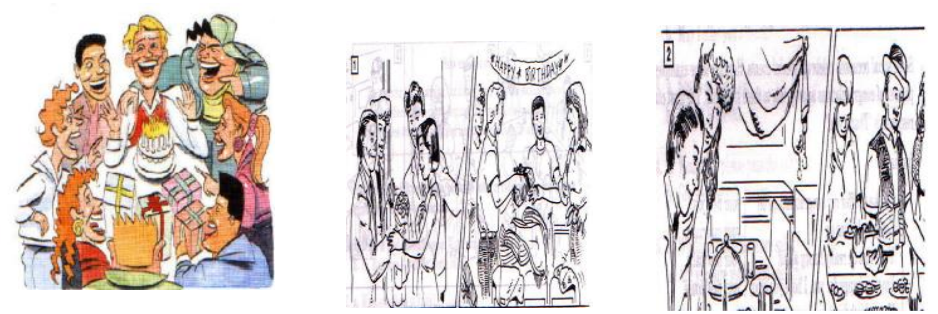

\section{Implementing}

To implement English teaching through guidance at SMP Al Akbar Brondong, there were some steps as follows: the teacher checked students' attendance, warming up to motivate students to study, grouping (a group consisted of four to five members), implementing the strategy in learning, and helping to the students had troubles in learning.

Read the following dialogues about complimenting. Practise reading them. Then, answer the questions that follow. You

Happy birthday, Ed. Wow, what a cool

Edo : Thanks. Yes, it's a birthday present from my aunt. She bought it in Singapore.

You : Lucky you! I wish I had a watch like that.

Edo : I hope you'll get a watch like this on your next birthday.

1) What are you complimenting?

2) Whom did Edo get the present from?

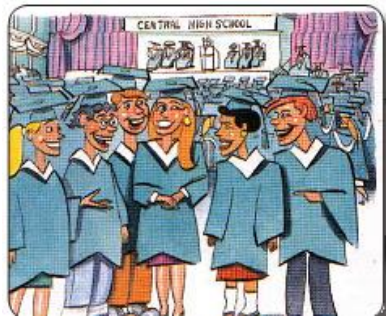

3) What is the occasion?

4) Why do they look happy?

5) What do they say to one another? 


\section{Observing}

The researcher observed learning and teaching used guidance. To know the result of students' achievement used guidance as model of learning, it could be explained as follows.

From the mean score 69.47 it will be showed the total students whose success or fail. The success students are 18 students or $56.25 \%$ from the total testees. And the students who fail in the test are 14 students or $43.75 \%$ from the total testees. It means that $56.25 \%$ the items test is easy from them.

Based on the analysis of teaching and learning process and the students' achievement in the first cycle, the implementation of guidance had not met the criteria of success yet. For that reason, the researcher and his collaborator made a decision to continue the implementation of the study to the second cycle.

\section{The Second Cycle \\ Planning}

Based on the research findings in terms of the weaknesses in the first cycle, the researcher and collaborator made an improvement and revision preparation before conducting the teaching and learning process for the second cycle including: Making the lesson plan, preparing the instructional materials, preparing the instruments would be used for observation making media would be used in learning, such as picture, slide, real object and so on.

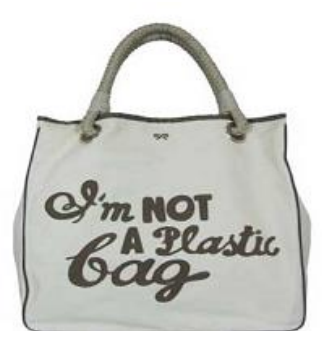

\section{Implementing}

As the first cycle, the implementation of the second cycle, the researcher acted as a teacher who conducted the teaching learning process, while the collaborator assisted to observe the teaching and learning process. The collaborator was also expected to write comments, either positive or negative, on the teaching and learning process, and identify the problems that might emerge during the teaching learning process. The implementation of the action was elaborated below: Giving warming up to motivate the students before studying, giving information to the students about the result in cycle 1 , the teacher explained the material of learning, the students asked difficult material to the teacher, making group consist three to four students, and the teacher gave problem about the material, such as:

Read the following dialogues about complimenting Then, answer the questions that follow.

You : Excuse me, but I was just admiring you Stranger : Oh, thank you.

You : Could you tell me where you got it? I like that for a long time.

Stranger : It's from the Luggage Store in Plaza Ind You : Oh, thank you very much.

1) What were you admiring?

2) Where did the stranger buy it?

3) Mention expression of complimenting!

Stranger : Oh, I love your earrings, they are so bea 
(in a lift)

Based on the results of the You : Thank you. They're silver. teaching and learning process Stranger : I know. Are they Yogya silverahalysis and the scores of the You : No, they are Bali silver. I got thedentinubaldievement in the second Stranger : Oh, I see.

4) What are made of silver?

5) Where did you buy them?

The next, teacher checked the result of learning, assisting the student who had problems in learning, and giving reinforcement about the material of learning in order to remember.

\section{Observing}

Observing had acted when the students implemented learning activities, observing in this cycle was looking the subject of study when implemented guidance, the result of students in this step as follows.

\section{Reflecting}

The researcher and the collaborator made some reflections on the implementation in order to determine the success or failure of the action. The reflections were focused on analysis of the teaching and learning process and analysis of the students' final products. The analysis was based on the obtained data from the observation checklists, field notes, and students' achievement.

After the writer computation of the mean score in this chapter, he found that the student's learning that shows their mean score around 75.38. From the mean score will be showed the total students whose success or fail. The success students are 24 students or $75 \%$ from the total testees. And the students who fail in the test are 8 students or $25 \%$ from the total testees. It means that $75 \%$ the items test is easy from them. cycle, it can be inferred that guidance could improve the students' achievement. This can be examined from the criteria of success described in this research. The students enjoyed learning using problem based learning. This can be seen from students' enthusiasm and motivation in following the activities, the students expressed without hesitation. Accordingly, it was considered reasonable to terminate the classroom action research.

\section{Discussion}

To know whether or not the teaching and learning process was successful, there must be an improvement on students' achievement. In this study, there has been a significant improvement on students' achievement compared with the teaching and learning process of achievement before using guidance was implemented.

The findings of this research showed that the students' achievement had improved significantly from one cycle to the following cycle. This could be seen from the results of each cycle. The first cycle had been implemented, the average score became 69.47. And the average score in the second cycle was 75.38. It means that the average score improve 5.91 from the first cycle to the second cycle. Since the mean score for every cycle show significant improvement and at the second cycle had met the criteria of success, the study can be stated as a 
successful piece of research. The improvement of students score can be seen in Figure 2.

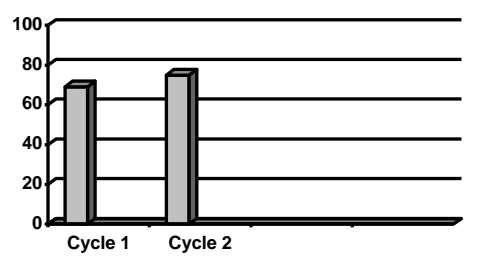

\section{Conclusion And Suggestion Conclusion}

Based on findings and discussion, finally the writer can take conclusion as follows: The students' achievement used guidance at SMP Al Akbar Brondong could be looked from the result of research. The first cycle had been implemented, the average score became 69.47. And the average score in the second cycle was 75.38. It means that the average score improve 5.91 from the first cycle to the second cycle. Since the mean score for every cycle show significant improvement and at the second cycle had met the criteria of success, the study can be stated as a successful piece of research.

\section{Suggestions}

Based on conclusion above, the writer can give suggestion, that: The students are expected to use brainstorming learning. Because the result of research shows that there is influence of guidance to the students' achievement, the teacher applies guidance.

\section{Bibliography}

Chisholm. 2000, Guiding Youth in the Secondary School, America Book Company, New York.

Cohen. 2002, Children in Trouble, Norton, New York.

Davis. 1999, Guidance Handbok for Teachers, McGraw-Hill, New York.

Froehlich. 1989, Guidance Services in Smaller School, McGrawHill, New York.

Lester D. Crow, and Alice Crow. 2004, Educational Psychology, America Book Company, New York.

Lester D. Crow, and Alice Crow. 2006, Human Development and Learning, America Book Company, New York.

Symonds. 1999, The Dynamics of Parent-Child Relationship, Columbia University Press, New York.

Torgerson. 2007, Studying Children, The Dryden Press, New York. 
Rohmat Qosyim

358 Annaba : Jurnal Pendidikan Islam 